\title{
Tematske i agentivne konstrukcije „straha" izvedene iz opojmljivanja unutarmjesnoga prostornog odnosa kodiranog prijedlogom ,u"
}

\begin{abstract}
Perak Benedikt, Tematska i agentivna opojmljivanja ,straha” izvedena iz unutarmjesnoga prostornog odnosa kodiranog prijedlogom , $u$ " (Thematic and Agentive Construction of strah [Fear] in Croatian Derived from the Conceptualization of Spatial Relations Coded by Preposition $u$ [in]). "Poznańskie Studia Slawistyczne" 9. Poznań 2015. Publishing House of the Poznań Society for the Advancement of the Arts and Sciences, pp. 333-352. ISSN 2084-3011.

This article presents an emergent model of the conceptualization of strah (Fear) in Croatian with focus on the constructions derived from the container image schema coded by preposition $u$ (in). the semantic and syntactic analysis of the collocations of lexeme strah demonstrates conceptual hierarchy of the activation of metonymic and metaphoric processes via syntactic organization and perspectivization. It is argued that the meaning of the lexeme strah is conceptualized by metonymic profiling sensory-motor correlates of affective states and by superimposing metaphorical mappings of objects, spatial relations, object/entities with thematic and agentive roles that are organized in an emergent system of respective ontological, spatial, thematic and agentive patterns of linguistic constructions.
\end{abstract}

KeYwords: emotion; fear; spatial constructions; thematic constructions; agentive constructions; perspectivization; emergent system

\section{Proizlazni sustav enciklopedijskog znanja o emotivnim stanjima}

U ovom se radu opisuje gradba pojmovnog sadržaja emocionalnog leksema „strah” procesom metaforičkog preslikavanja unutarmjesnoga prostornog odnosa kodiranog prijedlogom „u”. Glavni je cilj objasniti kognitivne procese koji omogućuju agentivnu konstrukciju značenja jezičnih iskaza kao u primjeru (1), u kojima se „strah” opojmljuje kao agentivni entitet sa svojstvima sILE ili OSOBE, iz predodžbeno jednostavnijih tematskih konstrukcija poput (2), u kojima se „strah” opojmljuje kao OBJEKT sa svojstvima SPREMNIKA. 
(1) strah me obavija/sputava/zarobljava/steže/hvata.

(2) biti/držati u strahu; tonuti u strah.

Opisi tematskih i agentivnih konstrukcija „straha” u radu predstavljaju dio teorijskog modela proizlaznog sustava enciklopedijskog znanja o emotivnim stanjima (Perak 2014). Temeljna je pretpostavka tog teorijskog modela da postoji hijerarhijska struktura opojmljivanja leksema emocionalnih stanja s proizlaznim sintaktičko-semantičkim obilježjima. Sastavnice „znanja o afektivnom stanju «straha»" niže razine nužne su za uspostavljanje proizlaznih (emergentnih), hijerarhijski viših, razina. Svaka nova proizlazna razina u pojmovnom smislu uključuje pojmovnu strukturu prethodnih razina, ali i ističe nove procese gradbe značenja stvarajući nova semantičko-sintaktička obilježja opojmljivanja leksema. Proizlazna hijerarhija jezičnih mehanizama gradbe pojmovnog sadržaja leksema „strah” klasificirana je na: 1) senzorno-motorne metonimijske te 2) metaforičko-ontološke, 3) prostorne, 4) tematske i 5) agentivne obrasce opojmljivanja.

Temeljnu razinu opojmljivanja značenja leksema „strah” čine metonimijski obrasci senzorno-motornih ishodišnih domena. Oni tvore semantičko-sintaktičke konstrukcije metonimijskog isticanja fizioloških reakcija i dijelova tijela koji se povezuju s afektivnim iskustvom straha: FIZIOLOŠKA REAKCIJA/DIO TIJELA ZA STRAH. Temeljnost isticanja fizioloških reakcija u jezičnoj komunikaciji emocija može se povezati s važnim epistemološkim problemom intersubjektivne sumjerljivosti afektivnih stanja: „kako znamo kakav je to osjećaj (kojeg druga osoba naziva) strah"? Ističući DIO ZA CJELINU metonimijski obrasci aktiviraju predodžbe o kakvoći afektivnog stanja.

(3) On se trese od straha.

FIZIOLOŠKA REAKCIJA TRESTI STOJI ZA STRAH > pobuđeno afektivno stanje negativne hedoničke valencije.

Prema brojnim neurokognitivnim istraživanjima (Rizzolatti, Sinigaglia 2008; Pineda 2009) spoznajni se mehanizam predodžbe afektivnog stanja može povezati sa sustavom zrcalnih neurona. Taj neuralni sustav na temelju motrenja reakcija drugih osoba aktivira u motoričkim dijelovima mozga zrcalnu predodžbu motoričkih radnji proizvodeći mentalnu simulaciju sumjerljivih fizioloških reakcija afektivnih stanja. Na temelju navedenih postavki tvrdi se da su senzorno-motorni obrasci opojmljivanja 
ključni za gradbu značenja leksema „strah”, odnosno da je značenje leksema „strah” utemeljeno na znanju o (prototipskim) „obilježjima afektivnog stanja" koje u jezičnoj komunikaciji oblikuju metonimijske konstrukcije.

Hijerarhijski nadređeni senzorno-motornim obrascima su ontološki obrasci opojmljivanja. Oni tvore kognitivni mehanizam kojim se afektivna stanja s prototipnim obilježjima „straha” opojmljuju kao OBJEKT/ENTITET. Pojmovna se struktura leksema „strah" u tim obrascima gradi metaforičkim preslikavanjem egzistencijalnog značenja OBJEKT u jezičnim konstrukcijama s glagolima poput „,biti” i ,postati”.

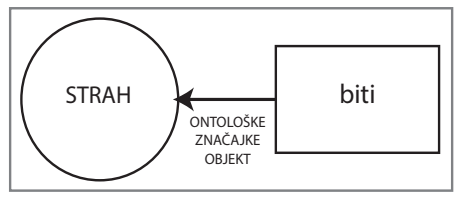

Slika (1) Shematski prikaz metaforičkog preslikavanja

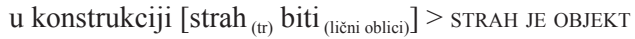

Pripisana egzistencijalna svojstva OBJEKTA u ontološkim konstrukcijama predstavljaju ontološki temelj daljnjega strukturnog opojmljivanja. S obzirom na veliku shematičnost glagola „biti” i nisku razinu detaljnosti pojmovnog sadržaja, ontološke se konstrukcije u pravilu opojmljuju pomoću dopuna, odnosno imenskog predikata.

(4) $[\text { Strah je }]_{\text {bivanje }}[$ najinstinktivnija] [emocija].

STRAH JE OBJEKT (SA SVOJSTVOM) (koje se pripisuje kategoriji EMOCIJA).

U takvim se konstrukcijama očituje znanje o afektivnom stanju straha, ali se istovremeno različitom semantičko-sintaktičkom organizacijom aktiviraju kognitivni modeli jednačenja, kategorizacije (4), metaforičkog preslikavanja i pojmovnog miješanja opojmljujući SVOJSTVA straha kao shematskog OBJEKTA.

Na sljedećoj se hijerarhijskoj razini „strah” opojmljuje kao овJEKT u određenim prostornim odnosima. Takve se jezične konstrukcije mogu nazivati prostornim obrascima opojmljivanja. Hijerarhijski nadređeni odnos ontološkim obrascima pripisan im je jer se tek opojmljivanjem ,straha” kao овJEKTA može govoriti o prostornim odnosima OBJEKTA. 


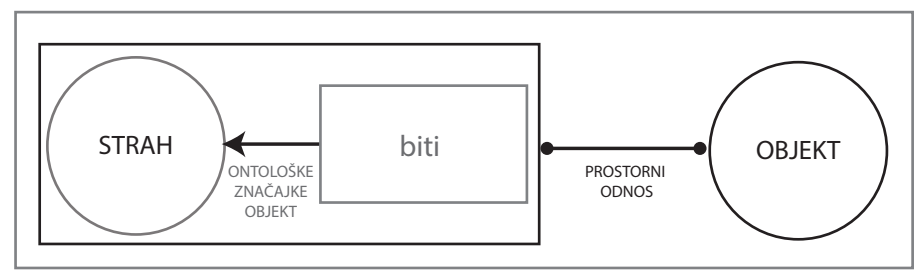

Slika (2) Shematski prikaz razrade ontološkog opojmljivanja prostornim obrascima ([STRAH JE OBJEKT $] \longleftrightarrow$ OBJEKT)

U jezičnim konstrukcijama s prijedlozima poput: „u”, „od”, ,iz”, „s(a)”, „za”, „na”, „o”, „uz”, „kroz”, ,pred”, „do”, „protiv”, „unatoč”, „prema”, „pod”, „nakon”, ,po”, „među” itd. izriču se različita prostorna značenja (Silić, Pranjković 2005: 245-250). Iz prostornih značenja navedenih prijedloga mogu se izvesti vremenska i nedimenzionalna logička značenja. Lingvističke teorije koje zastupaju tezu o prostornoj naravi primarno neprostornih izraza poznate su pod nazivom lokalističke teorije ili teorije lokalizma (Anderson 1971; Belaj 2008: 2). Analiza se u ovome radu usredotočuje na značenja izvedena iz prostornog odnosa izraženog prijedlogom: ,u”. S gledišta teorije pojmovne metafore (Lakoff, Johnson 1980; Kövecses 2000), leksem „strah” kodiran u jezičnim konstrukcijama s prijedlogom „u” opojmljuje se ili kao OBJEKT U SPREMNIKU ili SPREMNIK.

Temeljem prostornih odnosa uspostavljaju se tematski procesni obrasci opojmljivanja ,straha”. Procesni obrasci dodatno ističu promjenu odnosa i/ili prijenos energije među sudionicima, koja se tipično kodira glagolom. Kodiranje procesa ističe postojeći prostorni odnos između sudionika.

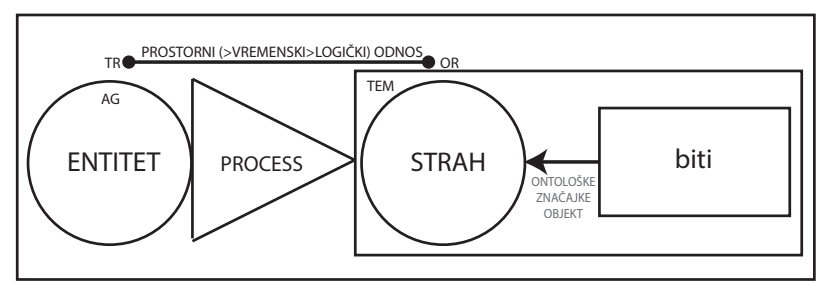

Slika (3) Shematski prikaz opojmljivanja leksema „strah” tematskim procesnim obrascima 
Tematski procesni odnosi opojmljuju leksem „strah” kao oвJEKT ili SPREMNIK na mjestu orijentira procesa. Leksem ,strah” kodira se na mjestu orijentira procesa, (izravnog ili neizravnog) objekta s tematskim semantičkim ulogama ništičnika, pokretnika ili trpnika ${ }^{1}$. ENTITET kodiran na mjestu trajektora preuzima semantičke uloge vršnika (5) ili trpnika/doživljavatelja (6).

(5) Marko ${ }^{\text {VRŠ }}$ ulijeva $\operatorname{strah}^{\mathrm{NIŠ}}$ u kosti protivnika ${ }^{\mathrm{ISK}}$.

(6) Marko $^{\text {TRP/DOŽ }}$ tone u strah ${ }^{\mathrm{NIŠ}}$.

Na posljednjoj se hijerarhijskoj razini „strah” sintaktički kodira na mjestu trajektora preuzimajući semantičke uloge vršnika ili instrumenta pa se takve konstrukcije nazivaju agentivnim procesnim obrascima.

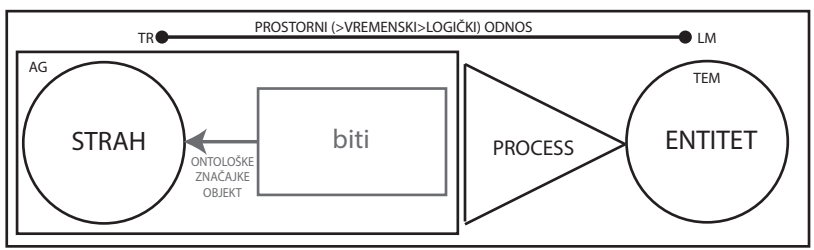

Slika (4) Shematski prikaz opojmljivanja leksema „strah” agentivnim procesnim obrascima

Navedene razine čine proizlazni sustav enciklopedijskog znanja o leksemu „strah”. Analiza se u ovome radu usredotočuje na tvorbu proizlaznih struktura tematskih i agentivnih obrazaca izvedenih iz prostornih obrazaca kodiranih prijedlogom „u” na temelju korpusa. U nastavku se opisuje prostorna, tematska i agentivna razina konstrukcija leksema „strah" i pojmovna motiviranost tematskih i agentivnih konstrukcija

${ }^{1}$ Prema Ronaldu Langackeru (2008: 357) agentivne i tematske uloge dvije su asimetrične vrste semantičkih uloga koje nastaju iz opojmljivanja aktivnosti ili pasivnosti sudionika u kanonskom modelu događaja. Agentivne semantičke uloge vršnika i instrumentala odražavaju svojstva svjesnih bića da svojevoljno djeluju, proširuju svoj utjecaj silom i energijom, ili da različitim sredstvima ostvaruju i održavaju nadzor nad okolinom. S druge strane, tematske semantičke uloge poput trpnika, doživljavatelja i ništičnika (eng. zero) pripadaju pasivnoj postavi događaja, lokacijama, stabilnim odnosima, oblicima i svojstvima. 
u prostornim obrascima opojmljivanja spremničkog odnosa kodiranog prijedlogom „u”. Za svaku razinu opisane su konstrukcije identificirane semantičko-sintaktičkom analizom 14875 pojavnica leksema „strah” i njezinih konkordancija dobivenih iz korpusa tekstova iz Hrvatske jezične riznice ${ }^{2}$ i Hrvatskog nacionalnog korpusa ${ }^{3}$, sveukupne građe od 131,8 milijuna pojavnica (Mw).

\section{Prostorni obrasci opojmljivanja kodirani prijedlogom , u"}

Prostor je jedna od temeljnih kategorija u odnosu na koju se organizira otjelovljena spoznaja (Barsalou 2008). Prijedlozi, prema kognitivnolingvističkim postavkama, shematski kodiraju prostorni suodnos dvaju (ili više) objekata (entiteta). Oni se stoga na razini kognitivnih funkcija mogu smatrati modifikatorima odnosa između dvaju (ili više) objekata ([овJект PRIJEDLOG $_{\text {modifikator odnosa }}$ OBJEKT $\left._{2}\right]$ ).

Kognitivni lingvisti tvrde da jezična konstrukcija kodiranih odnosa zrcali spoznajnu strukturu percepcije lika u odnosu na referentnu pozadinu. Leonard Talmy objekt kojem se određuje smještaj naziva primarnim objektom, a referentni objekt sekundarnim objektom ${ }^{4}$. Ronald Langacker ističe da se u jezičnoj konstrukciji uprizorenja prostornih odnosa primarni objekt najčešće kodira na mjestu predmetnog lika kojeg on naziva trajektor (tr), a sekundarni objekt na mjestu pozadnog lika kao orijentir (or) (Langacker 2008: 357). U jezičnim konstrukcijama prostornih odnosa leksički pojam „strah” može se pojaviti na mjestu trajektora ili orijentira. Time se shematski razlikuju dvije temeljne vrste prostornih konstrukcija „straha”.

(7) Čovjek osjeća [strah ${ }_{(t r)}$ u dubini svoga bića $\left.{ }_{(\text {or }}\right]$. [STRAH $_{\text {(tr) }}\left(\right.$ PROCES $^{5}$ PRIJEDLOG $_{\text {modifikator odnosa }}$ ENTITET $\left._{\text {(or })}\right]$

${ }^{2}$ Hrvatska nacionalna riznica, <http://riznica.ihjj.hr>, 20.03.2014.

${ }^{3}$ Hrvatski nacionalni korpus, <http://filip.ffzg.hr/bonito2/run.cgi/first_form>, 20.03.2014.

${ }^{4}$,The Figure is a moving or conceptually movable entity whose site, path, or orientation is conceived as a variable the particular value of which is the relevant issue. The Ground is a reference entity, one that has a stationary setting relative to a reference frame, with respect to which the Figure's site, path, or orientation is characterized" (Talmy 2000: 183-184).

${ }^{5}$ Iz ontoloških razloga, podrazumijeva se da je temeljni pojmovni proces u navedenim konstrukcijama pasivno egzistencijalno stanje biti, kao u primjeru (7), čak i ako nije leksički 
(8) $\left[\right.$ Stanari $_{(\text {tr) }}$ žive u strahu (or) $_{\text {Zive }}$.

[ENTITET $_{\text {(tr) }}$ (PROCES) PRIJEDLOG modifikator odnosa STRAH $\left._{(\text {or })}\right]$

U jezičnim konstrukcijama s prijedlogom „u” izriče se značenje unutarmjesnosti trajektora u orijentiru. Unutarmjesnost se opojmljuje predodžbenom shemom SPREMNIK koja podrazumijeva prostorni odnos u kojem se OBJEKT kodiran na mjestu trajektora nalazi unutar SPREMNIKA kodiranog na mjestu orijentira. Unutarmjesno opojmljivanje „straha” oblikuje pojmovnu metaforu STRAH JE OBJEKT U SPREMNIKU/SPREMNIK. Kodiran na mjestu trajektora STRAH $_{\text {(tr) }}$ (PROCES) $u_{\text {unutarmjesnost }}$ ENTITET $_{(\text {or) }}$ ] leksem „strah” opojmljuje se kao OBJEKT unutar granica SPREMNIKA, dok se u konstrukcijama ENTITET $_{(\text {tr })}$ (PROCES) $u_{\text {unutarmjesnost }}$ STRAH $\left._{(\mathrm{or})}\right]$ kodiran na mjestu orijentira leksem strah opojmljuje kao SPREMNIK/MEDIJ (Lakoff 1987: 271) koji može zaprimiti ili obuhvatiti neki drugi OBJEKT.

U hrvatskome opojmljivanje odnosa nije uvjetovano samo značenjem mjesnosti prijedloga, već se konstrukcijama prijedloga s različitim kombinacijama padeža izriče i usmjerenost. Prema Ivi Pranjkoviću (1992: 22-23) prijedlozi uz orijentir u genitivu označavaju odstojanje ili ukazuju na polazište. Prijedlozi uz dativ najčešće označuju odnose kretanja između dvaju objekata s neizvjesnim dosizanjem cilja. Prijedlozi s akuzativom određuju mjesto jednog objekta u odnosu na drugi objekt koji označuje smjer ili cilj kretanja. U kombinaciji s lokativom prijedlozi određuju doseg i granice jednog objekta u odnosu na drugi. Prijedlozi s instrumentalom određuju mjesto jednog predmeta u odnosu na drugi. Shematizacijom prostornih odnosa moguće je navedena semantičko-sintaktička obilježja usmjerenja pojednostavljeno prikazati s četiri semantička padeža (Belaj 2009: 5). Semantički je lokativ padež statičnog odnosa, ablativ padež smjera udaljavanja od ishodišnog entiteta, adlativ padež približavanja do ciljnog entiteta, a perlativ padež smjera bez zadanog ishodišnog ili ciljnog orijentira.

U hrvatskome se prijedlog ,u” kombinira s orijentirom u akuzativu i lokativu, rjeđe s orijentirom u genitivu (Šarić 2008; Kerovac 2012;

izraženo. U konstrukcijama se pojavljuju i drugi procesi (glagoli) čiji je pojmovni sadržaj motiviran upravo razradom prostornih odnosa. Oni su na ovoj razini analize prikazani sivom bojom jer u kognitivnom smislu predstavljaju kodiranje nove vrste pojmovnog sadržaja „o procesima” koja proizlazi iz percepcije prostornih odnosa. 
Matovac 2013), što znači da se kombinacijom u+akuzativ tipično izražava značenje dinamične unutarmjesne adlativnosti, a kombinacijom u+lokativ statična unutarmjesna lokativnost.

U nastavku slijedi korpusna analiza prostornih obrazaca u kojima je „strah” kodiran na mjestu:

a) trajektora $\mathrm{s}$ orijentirom $\mathrm{u}$ akuzativu ili lokativu [STRAH $\mathrm{Str}_{(\mathrm{r})}$ (PROCES) u ENTITET (or)(ak./lok.)];

b) orijentira u akuzativu [ENTITET (tr) $_{\text {(PROCES) }} \mathrm{u}_{\text {strah }}$ (or)(ak.) $_{\text {; }}$;

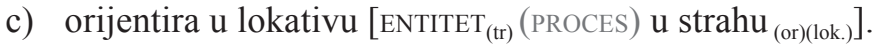

2.1. Unutarmjesni prostorni obrasci STRAH JE OBJEKT U SPREMNIKU

$$
\text { (u+ak./lok.) }
$$

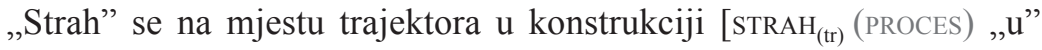

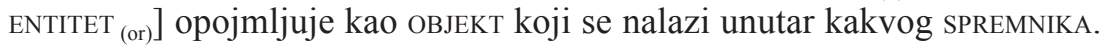
Kolokacija [,strah u” ENTITET] pojavljuje se 339 puta. Konstrukcije opisuju statičnu unutarmjesnost „straha” u SPREMNIKU ili adlativni proces ulaženja „straha” u SPREMNIK. Vrste SPREMNIKA su obično osobe (9), ali i dijelovi tijela koji metonimijski ukazuju na doživljavatelja, poput „očiju” (10), „kosti” (11), „lica, duše” itd.

(9) ...niti više straha u njoj ne bijaše... (Kraljević).

(10) ...s tugom i strahom u očima... (Novak).

(11) ...uhodama utjeralo tolik strah u kosti da su se razbježale... (,Vjesnik”).

Ove konstrukcije odražavaju uvid da se afektivno stanje može očitovati na određenim dijelovima tijela, pri čemu se dio tijela opojmljuje kao SPREMNIK. One u određenoj mjeri predstavljaju metaforičku nadogradnju metonimijskog profiliranja fizioloških obilježja afektivnog stanja „straha”.

Metaforizacija se još više očituje u pojmovnom spajanju prostornog opojmljivanja ,straha” konstrukcijom [ $\operatorname{STRAH}_{(\text {(tr) }}$ (PROCES) u ENTITET (or)] s profiliranjem orijentira metonimijom MJESTO ZA STANOVNIKA čime se ističe skupni doživljaj afektivnog stanja ,straha” (12). 
(12) A kada sam mu ispričao kako su duševni bolesnici, nakon bombardiranja umobolnice lutali kroz polja i vinograde, lunjali kroz šume, izazivajući strah u okolnim selima... (Horvatić).

Daljnjim proširenjem metaforičkog poimanja STRAH JE OBJEKT/SJEME i spajanjem s metonimijskim poimanjem MJESTO ZA DOŽIVLJAVATELJA stvara se složena metafora STRAH JE SJEME/BILJKA koje se može ,posijati” (13), „usaditi” (14) itd. na određenom MJESTU/DOŽIVLJAVATELJU.

(13) ETA iskoristila svoje primirje za pripremu novog vala atentata, koji treba pokazati ,njezinu moć” i posijati strah u Španjolskoj (,Vjesnik”).

(14) Usadi strah u njih, Bože (,,Vjesnik”).

Iz navedenih se primjera uočava da leksem „strah” u konstrukcijama $\left(\mathrm{STRAH}_{\text {(tr) }}\right.$ (PROCES) u ENTITET $\left._{\text {(or) }}\right]$ nizom metonimijskih i metaforičkih procesa proširuje svoje značenje, međutim ,znanje o strahu” na ovoj razini pojmovne gradbe ne proizlazi samo iz afektivnih obilježja, već i iz ,znanja o svojstvima" OBJEKTA U SPREMNIKU.

S obzirom na kombinacije padeža može se uočiti da konstrukcija $\left[\mathrm{STRAH}_{(\text {tr })}(\right.$ PROCES $) \mathrm{u}$ ENTITET $\left._{\text {(or)(ak.) }}\right] \mathrm{s}$ orijentirom u akuzativu oblikuje adlativni odnos, kao u primjerima (11), (14), što se shematski može prikazati na sljedeći način:

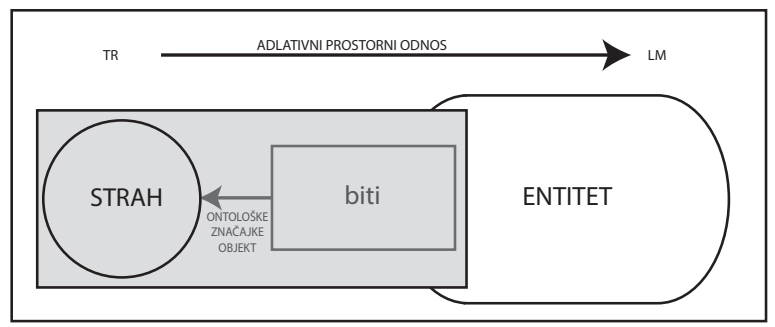

Slika (5) Shematski prikaz adlativnog odnosa u konstrukciji

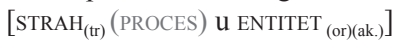

Nasuprot tomu, konstrukcija [ $\mathrm{STRAH}_{\text {(tr) }}$ (PROCES) „u” ENTITET (or)(lok.)] ističe lokativni odnos koji ima obilježja okruženosti, statičnosti, kao u primjerima (9), (10), (12), (13), što je shematski prikazano na slici (6): 


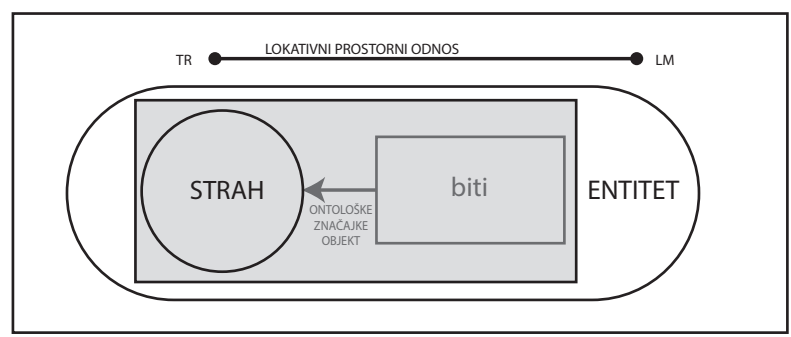

Slika (6) Shematski prikaz adlativnog odnosa u konstrukciji $\left[\operatorname{STRAH}_{\text {(tr) }}\left(\right.\right.$ PROCES) $^{\mathrm{u}}$ ENTITET $\left._{\text {(or)(lok.) }}\right]$

2.2. Adlativni unutarmjesni prostorni obrasci STRAH JE SPREMNIK (u+akuzativ)

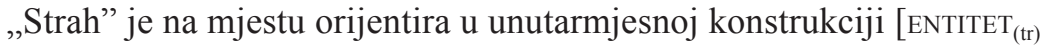
(PROCES) u strah ${ }_{\text {(or)(ak.) }}$ zabilježen u 31 pojavnici $(\mathrm{n}=31)$.

(15) Ostajemo dosljedni, iako je većina stranaka natjerala birače u strah („Glas Slavonije").

(16) ...ono se širilo po čitavom njemu, oduzimalo mu snagu, slabilo volju, sav se pretvarao u strah (Šegedin).

(17) Dišpet nije nikakav argument, dišpet vrlo lako preraste u strah (Samovojska).

Akuzativni oblik orijentira „strah” opojmljuje adlativni smjer kretanja trajektora prema „strahu” kao CILJU. Konstrukcija stoga aktivira prostornu predodžbu unutarmjesnosti OBJEKTA u SPREMNIKU po dovršenju kretanja, što se metaforički preslikava na značenje usmjerenja prema postupnoj obuhvaćenosti doživljavatelja afektivnim stanjem „straha”.

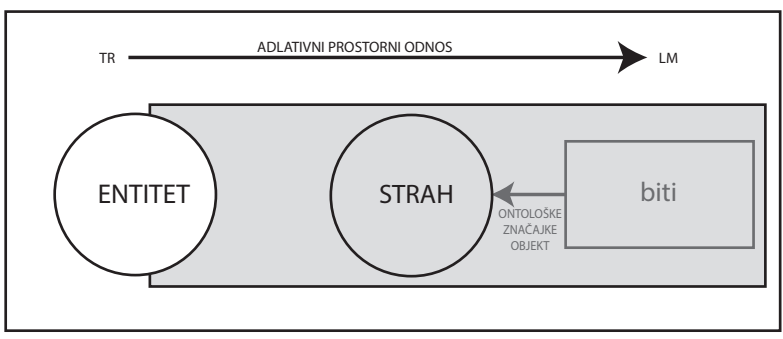

Slika (7) Shematski prikaz opojmljivanja konstrukcije

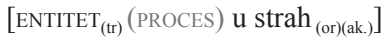




\subsection{Lokativni unutarmjesni prostorni obrasci STRAH JE SPREMNIK}

$$
\text { (u+lokativ) }
$$

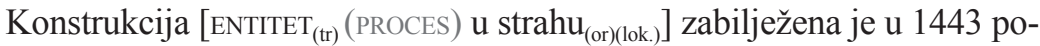
javnice. Visoka čestotnost ukazuje na konvencionalnost i kognitivnu usađenost lokativnoga unutarmjesnog opojmljivanja ,straha” kao SPREMNIKA u kojem se nalazi doživljavatelj. Takvo je unutarmjesno opojmljivanje često i za ostala mentalna stanja (Lakoff 1987; Kövecses 2002) što se shematski može iskazati metaforom MENTALNA STANJA SU SPREMNICI (ZA DOŽIVLJAVATELJA) ${ }^{6}$.

(18) Postupno je stao provoditi manje vremena u spavanju (Orwell).

(19) To je inače posve normalno emocionalno stanje koje nas drži u budnosti, pripravnosti... (,Vjesnik”).

Prijedlog ,u” u kombinaciji s lokativnim oblikom ,strahu” prototipno izražava statičnu unutarmjesnost doživljavatelja u afektivnom stanju.

(20) Hrvati u BiH u strahu od izbornog inženjeringa („Vjesnik”).

(21) Nisam bila u strahu, znala sam da mi je sir dobar (,Vjesnik”).

(22) Čudno je, a ponekad i veoma bolno, vidjeti ljude u strahu (<glas-koncila.hr>)

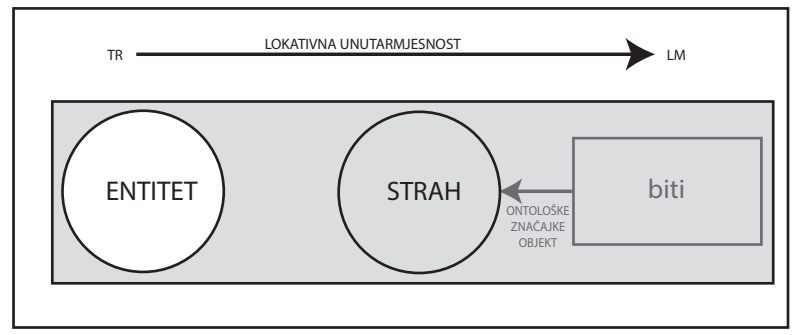

Slika (8) Shematski prikaz opojmljivanja konstrukcije $\left[\operatorname{ENTITET}_{(\mathrm{tr})}(\right.$ PROCES$)$ u strahu $\left._{\text {(or)(lok.) }}\right]$

${ }^{6}$ Takvo jezično opojmljivanje upućuje na odvojenu kategorizaciju nositelja svjesnosti/ sebe/ja od mentalnog stanja. Različitost opojmljivanja kategorija sebe i mentalnih stanja otvara barem dvije oprečne mogućnosti tumačenja naravi sebstva. Jedna se uklapa u dualističko poimanje metafizičke esencije sebe/ja apstrahirane od konkretnih sastavnica kao što su tijelo, osjećaji, mentalna stanja. Druga je vezana uz poimanje sebe kao proizlazne razine konstruirane iz sastavnica tijela, mentalnih stanja i simboličke stvarnosti kulture (Perak, Puljar D’Alessio 2013). 


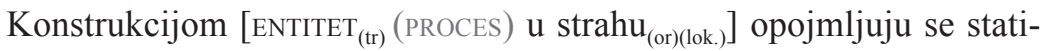
čne značajke unutarmjesnoga prostornog odnosa OBJEKTA U SPREMNIKU: pounutrašnjenost, pohranjenost, omeđenost i zatvorenost.

\section{Tematski procesno unutarmjesni obrasci}

Tematski procesno unutarmjesni obrasci izražavaju se konstrukcijama u kojima se leksem „strah” opojmljuje kao SPREMNIK i kodira na mjestu izravnog sintaktičkog objekta (a), ili na mjestu neizravnog sintaktičkog objekta (b).

a) ENTITET $_{(\text {tr })}$ PROCES (PRIJEDLOG $\left._{\text {modifikator odnosa }}\right)$ STRAH $_{(\text {or })}$ ];

b) $\left[\right.$ ENTITET $_{(\text {tr })}$ PROCES ENTITET $_{(\text {or 1) }}$ (PRIJEDLOG $\left._{\text {modifikator odnosa }}\right)$ STRAH $\left._{(\text {or } 2)}\right]$.

Motiviranost procesa u unutarmjesnim tematskim obrascima „straha” shematski proizlazi iz prostornih odnosa koji se mogu podijeliti na:

a) lokativno unutarmjesni odnos - statični odnos u SPREMNIKU;

b) unutarmjesni adlativni odnos - predodžbena shema PUNJENJA SPREMNIKA.

\subsection{Tematska unutarmjesna opojmljivanja lokativnog odnosa}

U tematskim procesnim unutarmjesnim obrascima „strah” se opojmljuje kao SPREMNIK. Doživljavatelj se opojmljuje kao oBJEKT u SPREMNIKU. Značenje pounutrašnjenosti, pohranjenosti, omeđenosti, sputanosti i zatvorenosti prostornih konstrukcija s orijentirom u lokativu uvjetuje i vrstu procesa koji se najčešće pojavljuju u tematskim konstrukcijama, poput glagola apstraktnih stanja „biti” i ,živjeti” $(\mathrm{n}=185)$ ili statičnih procesa poput „držati” $(n=10)$ ili ,skrivati” $(n=16)$ itd.

Kao primjer tematskih konstrukcija analizira se glagol „držati”. Prijelazni glagol držati u konstrukcijama sa „strahom” javlja se u 27 pojavnica. Od toga u tematskim unutarmjesnim konstrukcijama [ENTITET $1_{(\mathrm{rr})}$ VRŠ držati ENTITET $2_{(\text {ak.)(or) }}$ TRP/DOŽ (u strahu) MODp] opojmljujući metaforu STRAH JE SPREMNIK u 14 pojavnica. Tek u jednoj pojavnici (24) „strah” je izravni objekt, odnosno trpnik procesa prizivajući vanmjesnu predodžbenu shemu držanja 
objekta i ishodišnu domenu OBJEKT. U ostalim konstrukcijama glagola „držati” opojmljuje se „strah” agentivno, odnosno kao vršnik $(n=12 / 27)$.

(23) Slovenci imaju ovakvu vlast, koja ih drži u strahu... („Nacional”).

(24) Znakovito je da se njima držalo u strahu cijelu populaciju („Nacional”).

(25) Tko se čvrsto ne drži straha Gospodnjeg kuća će mu brzo propasti (Stari zavjet).

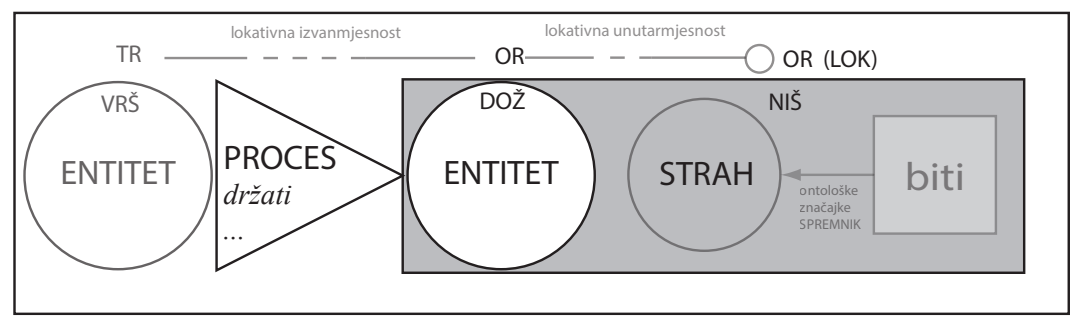

Slika (9) Shematski prikaz konstrukcije [ENTITET $1_{(\text {trr) }}$ VRŠ držati ENTITET $2_{\text {(ak.)(or) }}$ TRPPOOŽ (u strahu $)_{\text {MODp }}$ ]

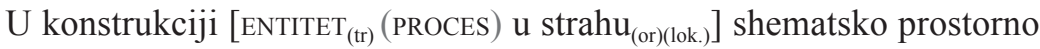
poimanje SPREMNIKA može se metaforički proširiti prema značenju TVARI koja zaprima određeni овJEKT. Prototipna tvar sa svojstvima zaprimanja objekta su TEKUĆINE. Iz pojmovne metafore STRAH JE TEKUĆINA (eng. FEAR IS A FLUID IN A CONTAINER) (Kövecses 2000: 23) izvode se tako konstrukcije s procesima poput „kupati se” $(n=2)$, ,utopiti” $(n=2)$ itd.

(26) ...kako se Mirko kupa u strahu, kao u vodi (Pavičić).

\subsection{Procesno-spremnička tematska opojmljivanja izvedena iz adlativnih odnosa}

Adlativno unutarmjesno opojmljivanje odgovara predodžbenoj shemi ULAŽENJE U SPREMNIK. U procesno-spremničkim tematskim opojmljivanjima „strah” je sPREMnIK, a objekt ulaženja je DOžIVLJAVATELJ. Najčešće se adlativno unutarmjesno opojmljivanje iskazuje s akuzativnim oblikom prijedložnog odnosa u + akuzativ konstrukcijama [ENTITET $_{(\text {tr) }}$ PROCES ENTITET $_{(\text {tr) }}$ $\left.\mathrm{u} \mathrm{strah}_{\text {(or)(ak.) }}\right] \mathrm{s}$ dinamičnim procesima poput: ,natjerati, nagoniti, pretvoriti, prerasti (u strah)". 


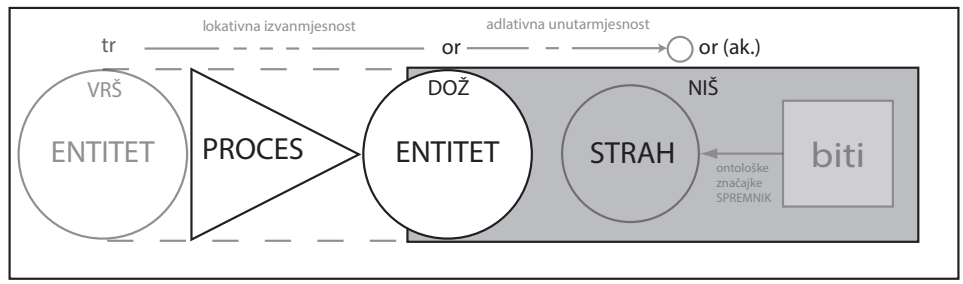

Slika (10) Shematski prikaz procesno-spremničkih tematskih opojmljivanja ,straha” izvedenih iz adlativnoga unutarmjesnog prostornog odnosa

„Strah” se opojmljuje kao SPREMnIK. Doživljavatelj je ENTITET u unutarmjesnom odnosu. Trajektor je vršnik procesa koji potiče adlativni odnos doživljavatelja i ,straha”. U neprijelaznim konstrukcijama [ENTITET PROCES u strah $\left.{ }_{\text {(or)(ak.) }}\right]$ izostavlja se vršnik (označeno bljeđom bojom vršnika), a u povratnim [ENTITET se PROCES u strah(or)(ak.) se spajaju domene vršnika i doživljavatelja (označeno iscrtanim linijama).

(27) Znaš što; mi ćemo njih utjerati u strah! (Nehajev).

Kao i u slučaju lokativnih odnosa spremnik se može dodatno opojmiti kao TEKUĆINA, pa se iz takvog adlativno unutarmjesnog opojmljivanja „straha” izvode dinamični procesi koji opisuju predodžbu PUNJENJA/ISPUNJAVANJA SPREMNIKA, poput ,tonuti u strah” i slični.

\section{Agentivni procesno unutarmjesni obrasci}

U skladu s postavkama proizlaznog sustava enciklopedijskog znanja agentivni obrasci lokativnoga spremničkog opojmljenja „straha” izvode se iz tematskih obrazaca u kojima se ,strah” tematski opojmljuje kao SPREMNIK. Sintaktičkom organizacijom leksem „strah” premješta se s tematskih uloga ništičnika ili trpnika na mjesto instrumenta ili vršnika. Osobitost gradbe pojmovnog sadržaja „straha" u agentivnim procesnim obrascima proizlazi iz preslikavanja agentivnih obilježja trajektora kao pokretača energetskog i djelatnog lanca nekog procesa.

Temeljni mehanizam stvaranja novih pojmovnih obilježja u agentivno-procesnim obrascima iz jednostavnijih modela opojmljivanja leksema 
strah jest perspektivizacija. Perspektivizacija uključuje promjenu motrišta (slika 11 i 12). Uvid u kakav događaj ovisan je o odabiru jednog od mogućih motrišta iz kojih se određen prizor ili događaj može motriti. Iz tematske perspektive afektivno stanje ,straha” opojmljuje se kao pasivni sudionik OBJEKT ili SPREMNIK određenog procesa. Odabirom agentivnog motrišta afektivno stanje ,straha” se može opojmiti kao aktivni sudionik čime se ističu drugi kognitivni modeli djelovanja instrumenta ili osoBE stvarajući nove pojmovne implikacije.

U nastavku se opisuju agentivni procesni obrasci izvedeni iz unutarmjesnih: lokativnih odnosa i adlativnih odnosa.

4.1. Agentivni procesni obrasci izvedeni iz unutarmjesnih lokativnih odnosa

U agentivnim obrascima opojmljuje se perspektiva iz očišta SPREMNIKA - ,strah” koji postaje trajektor procesa (slika 11). Procesi u agentivnim lokativno spremničkim obrascima ističu okomjesnu lokativnost „straha” prema orijentiru, odnosno doživljavatelju.

U tematskim konstrukcijama ,strah” je pasivni SPREMNIK s ništičnom ulogom, dok je u agentivnim konstrukcijama vršnik radnje opojmljen kao SILA ili čak metaforički poosobljen kao osobA. Pojmovni sadržaj istog događaja promjenom perspektive kodira se na dva različita načina. S obzirom na nižu razinu složenosti pojmovne gradbe može se tvrditi da je tematsko opojmljenje ishodište agentivnog opojmljivanja leksema „strah”. Glagoli u agentivnim procesno spremničkim konstrukcijama vezani su uz predodžbenu shemu OKRUŽENJA, poput: „obaviti, sputati, obuzeti, držati, zarobiti, obuhvatiti" $(\mathrm{n}=3)$ itd. Perspektivizacijom tematske konstrukcije s neprijelaznim glagolom ,potonuti (u strah)” i metafore TEKUĆINA JE SPREMNIK mogu se izvesti agentivne konstrukcije s procesima kao što su: (,u/za) daviti” $(\mathrm{n}=2)$, ,preplaviti” $(\mathrm{n}=6)$,

Proces „obaviti” s istaknutim okomjesnim odnosom trajektora oko orijentira može se smatrati prototipnim primjerom agentivnog opojmljenja iz tematskoga lokativnog spremničkog opojmljivanja „straha”. U konstrukcijama s glagolom „obaviti” $(n=5)$,strah” je redovito kodiran kao vršnički entitet. 

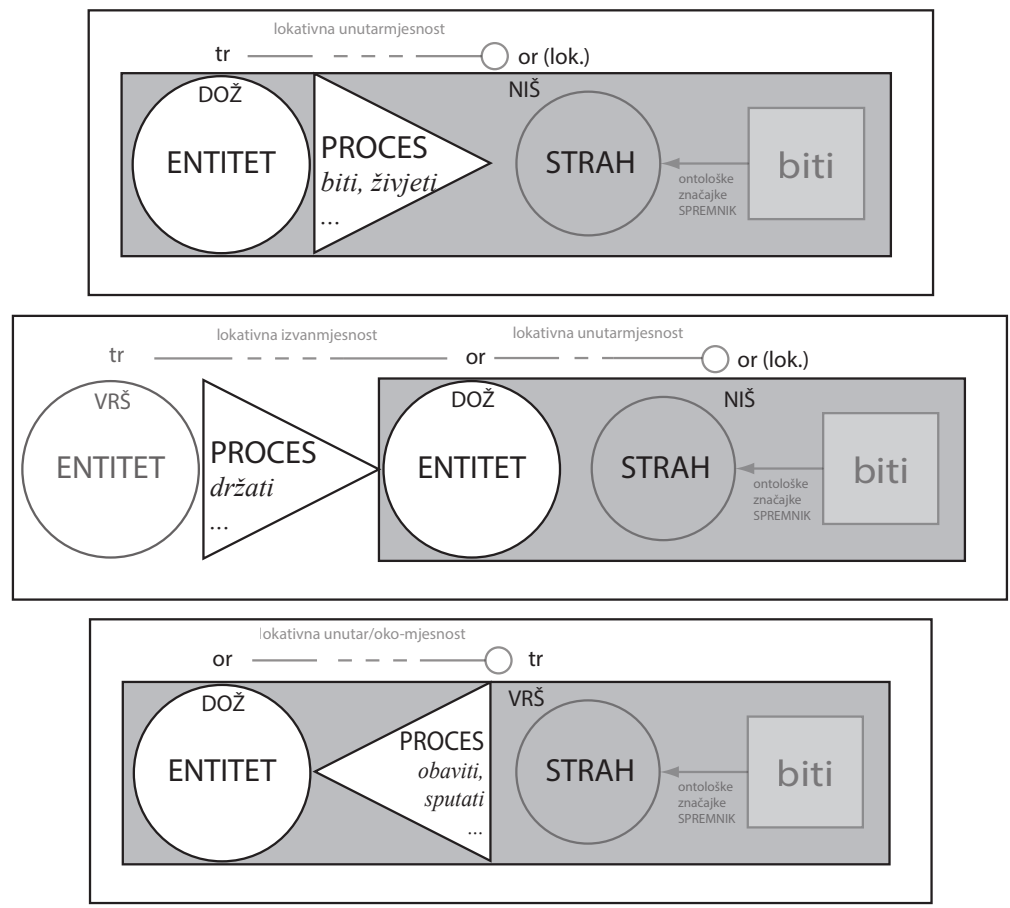

Slika (11) Shematski prikaz agentivnih obrazaca opojmljivanja ,straha” iz unutarmjesnoga lokativnog odnosa

(28) ...strah je čudnim sjajem kralja obavio... (Tomasović).

(29) ...obavio je i strah ljude: u njemu potonuše posvema (Šegedin).

Značenje leksema „strah” u tim konstrukcijama ističe obilježja SILE/ osoBE koja ima okomjesni, sputavajući učinak na trpnika - doživljavatelja.

4.2. Agentivni obrasci adlativno unutarmjesnog opojmljenja ,straha”

U adlativno unutarmjesnim agentivnim konstrukcijama „strah” se opojmljuje kao SPREMNIK u adlativnom odnosu prema doživljavatelju. Takve konstrukcije proizlaze iz tematskih unutarmjesnih opojmljivanja ,straha” u kojima procesi poput „tonuti” ističu adlativni smjer doživljavatelja 
u „strah” (slika 12). Promjenom perspektive ističe se adlativni odnos SPREMNIKA ,strah” prema doživljavatelju.
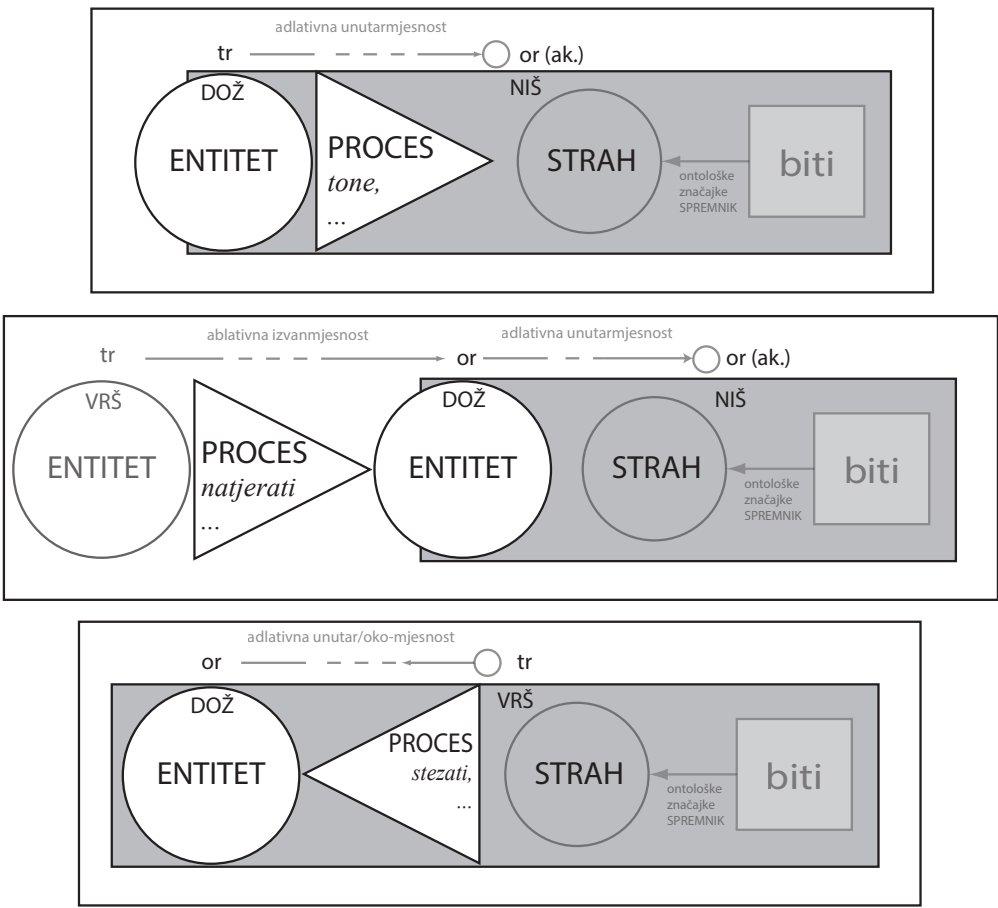

Slika (12) Shematski prikaz agentivnih obrazaca opojmljivanja ,, straha” iz unutarmjesnog adlativnog odnosa

Procesi u ovim konstrukcijama vezani su uz isticanje adlativnog odnosa, poput: „stezati, hvatati, popustiti, prožeti”. Za primjer se opisuje konstrukcija ,strah stezati”.

Glagol „stezati” ističe adlativno usmjerenu okomjesnu siLu trajektora SPREMNIKA u odnosu na orijentir. U konstrukcijama s leksemom „strah” glagol „stezati” pojavljuje se 12 puta. Od toga „strah” ima vršničku ulogu u 5 pojavnica $(n=5 / 12)(29)$, trpničku u $1(n=1 / 12)$ pojavnici $(30)$, a na mjestu priložne dopune uzroka, koja predstavlja ablativno opojmljivanje „straha” kao ISHODIŠTA, nalazi se 6 puta $(n=6 / 12)(31)$. 
(30) U strahu koji će ti stezati srce i od prizora što... (Stari zavjet).

(31) Kajiš stegni, strah pritegni, zube stisni, pa zakorači (Raos).

(32) Sve mi se srdce steže od straha, kad pomišljam na moga Juru... (Matko).

U usporedbi s lokativnim okomjesnim procesom „obaviti” ili „sputati”, proces „stezati” u konstrukciji [,strah stezati” ENTITET] ističe agentivnost ,straha” kao SILE ili OSOBE KOJA VRŠI SILU time što opojmljuje adlativni smjer djelovanja i kontakt s doživljavateljem. U agentivnim konstrukcijama „straha” izvedenim iz adlativnoga unutarmjesnog odnosa dodatno se ističe predodžbena shema SPREMNIK/SILA/OSOBA STEŽE/OBUHVAĆA OBJEKT (PREMA POTPUNOJ OKOMJESNOSTI/UNUTARMJESNOSTI).

\section{Zaključak}

Teorijski model proizlaznog sustava enciklopedijskog znanja pretpostavlja hijerarhijsku proizlaznu strukturu opojmljivanja leksema „strah” i drugih emocionalnih leksema. U ovome je radu prikazan proizlazni sustav „znanja o afektivnom stanju straha” temeljem uspostavljanja unutarmjesnog odnosa kodiranog u konstrukcijama leksema „strah” s prijedlogom „u”. U prostornim obrascima unutarmjesnog opojmljivanja očituje se iskustveno ,znanje o djelovanju afektivnog stanja straha” oblikovano metonimijskim i ontološkim obrascima, međutim ističe se preslikavanje kognitivnih modela „o prostornim odnosima između” OBJEKATA i SPREMNIKA te očituje ,jezično znanje" o konvencijama kodiranja prostornih odnosa u hrvatskome s obzirom na unutarmjesnu lokativnost kodiranu u+lokativ, odnosno unutarmjesnu adlativnost kodiranu u+akuzativ. U tematskim se procesnim unutarmjesnim konstrukcijama značenje istaknuto uspostavlja preslikavanjem „znanja o djelovanju procesa” na OBJEKTE i SPREMNIKE. PROCESI koji se javljaju u tematskim konstrukcijama proizlaze iz prostornog opojmljivanja lokativne unutarmjesnosti, poput „biti/živjeti/držati u strahu”, odnosno adlativne unutarmjesnosti, poput „natjerati u strah”. Perspektivizacijom se iz tematskih konstrukcija uspostavljaju agentivni obrasci u kojima se značenje istaknuto uspostavlja preslikavanjem kognitivnih modela ,znanja o agentivnim vršnicima procesa”, odnosno metaforičkim opojmljivanjem leksema ,strah” kao sILE ili (personificirane) osoBE KOJA VRŠI SILU. Središnja je ideja analize agentivno-procesnih obrazaca da 
opojmljivanje afektivnog stanja „straha” složenim ishodišnim domenama SILA i OSOBA ima svoju motivaciju u prethodno opisanim obrascima opojmljivanja: senzorno-motornim metonimijskim, ontološkim, prostornim i tematsko-procesnim obrascima. Drugim riječima, metafore STRAH JE SILA i STRAH JE OSOBA nisu arbitrarne već proizlaze iz umrežavanja jednostavnijih kognitivnih modela metonimijskog profiliranja, kategoriziranja „straha" kao OBJEKTA i SPREMNIKA te njihove shematične razrade.

Za razliku od tipično semantičko-pojmovnih analiza „straha” (Kövecses 1990: 74-82; 2000: 23; Oster 2012) u kojima se naglasak isključivo stavlja na analizu metonimijskih i metaforičkih mapiranja, semantičko-sintaktički pristup pokazuje da se metaforički procesi „straha” aktiviraju određenom jezičnom organizacijom. Svaka nova razina jezičnih konstrukcija u pojmovnom smislu uključuje pojmovnu strukturu prethodnih razina, ali i ističe nove procese gradbe značenja stvarajući nova proizlazna semantičko-sintaktička obilježja opojmljivanja leksema. Proizlazna obilježja oblikuju nove oblike pragmatičnih implikatura i pragmatične kontekstualizacije izražavanja afektivnog stanja.

Sintaktičko-semantički proizlazni model analize opojmljivanja leksema „strah" primjenjiv je i na lekseme drugih afektivnih stanja, kao i ostale ontološki subjektivne domene iskustva pružajući uvid u obrasce izražavanja subjektivnih stanja te biološku motivaciju, univerzalne kognitivne temelje i pragmatično-kulturne osobitosti njihovog opojmljivanja.

\section{Literatura}

Anderson J.M., 1971, The Grammar of Case. Towards a Localistic Theory, Cambridge. Barsalou L.W., 2008, Grounded cognition, „Annual Review of Psychology” br. 59, str. $617-645$.

Belaj B., 2008, Jezik, prostor i konceptualizacija. Shematična značenja hrvatskih glagolskih prefiksa, Osijek.

Belaj B., 2009, Prostorna značenja na razini složene rečenice, Osijek.

Kerovac B., 2012, Kognitivnolingvistička analiza prostornih odnosa u turskom i hrvatskom jeziku, doktorska disertacija, Zagreb.

Kövecses Z., 1990, Emotion concepts, New York.

Kövecses Z., 2000, Metaphor and Emotion. Language, Culture, and Body in human feeling, New York.

Kövecses Z., 2002, Metaphor. A Practical Introduction, New York. 
Lakoff G., Johnson M., 1980, Metaphors We Live By, Chicago.

Lakoff G., 1987, Women, fire, and dangerous things. What categories reveal about the mind, Chicago.

Langacker R., 2008, Cognitive Grammar. An Introduction, New York.

Matovac D., 2013, Semantika hrvatskih prijedloga, doktorska disertacija, Osijek.

Oster U., 2012, „Angst” and „Fear” In Contrast. A Corpus-Based Analysis Of Emotion Concepts, u: Cognitive Linguistics between Universality and Variation, ur. M. Brdar, I. Raffaelli, M. Žic Fuchs, Frankfurt a/M-Berlin-Bern-Bruxelles-New York-Oxford-Vienna.

Perak B., 2014, Opojmljivanje leksema strah u hrvatskome: sintaktičko-semantička analiza, doktorska disertacija, Zagreb.

Perak B., Puljar D’Alessio S., 2013, Kultura kao emergentno svojstvo otjelovljene spoznaje, u: Avanture kulture. Kulturalni studiji u lokalnom kontekstu, ur. N. Fanuko, S. Puljar D’Alessio, Zagreb.

Pineda J. (ur.), 2009, Mirror Neuron Systems. The Role of Mirroring Processes in Social Cognition, New York.

Pranjković I., 1992, Prostorna značenja prijedloga u hrvatskome standardnom jeziku, „Suvremena lingvistika” br. 33, str. 21-26.

Rizzolatti G., Sinigaglia C., 2008, Mirrors in the Brain. How We Share our Actions and Emotions, New York.

Silić J., Pranjković I., 2005, Gramatika hrvatskoga jezika za gimnazije i visoka učilišta, Zagreb.

Šarić Lj., 2008, Spatial Concepts in Slavic, A Cognitive Linguistic Study of Prepositions An Cases, Weisbaden.

Talmy L., 2000, Toward a Cognitive Semantics, Cambridge. 